\title{
The Educational Values of Oral Tradition as an Attempt to Preserve Customary Land in Ketapang District West Kalimantan
}

\author{
Basuki Wibowo', Dewi Liesnoor $\mathrm{S}^{2}$, Wasino ${ }^{3}$, Hermanu Joebagio ${ }^{4}$ \\ ${ }^{1}$ Graduate School, Universitas Negeri Semarang, Indonesia \\ ${ }^{23}$ Universitas Negeri Semarang, Indonesia \\ ${ }^{4}$ Universitas Sebelas Maret Surakarta, Indonesia \\ ${ }^{1}$ Corresponding email: $\underline{\text { che.khatulistiwa23@gmail.com }}$
}

\begin{abstract}
The high risk of forest fires in Ketapang Regency West Kalimantan is caused by many factors. One of them is the opening of a new farm by using fires of the forest. In line with this, educating people to care and to preserve the forest is a part of inseparable efforts from forest fire preservation. The purpose of this study was to dig the values from oral tradition and promote it in order to expand and preserve customary forest in Ketapang West Kalimantan. This study used qualitative approach as the research method. Meanwhile, the data validity was examined by using triangulation, while the data analysis was done interactively. The results of the study revealed that the oral tradition expanding in Dayak tribes has been used as studies resource and media for people. This tradition has been used as a learning media for people, such as arts performance education. As a learnt resource, the values of oral tradition contain educational values that could be expanding as a tool of enforcement, mobilization and socialization of the importance of environmental awareness for forest prevention from damage. At last, this study concludes that oral tradition values will establish a good characteristics by having a high social concern of the environment. By having this, it is hoped that the forest fire will reduce.
\end{abstract}

Keywords: oral tradition, educational values, and forest preservation.

\section{Introduction.}

Forest is one of a natural resources located in West Kalimantan. Its existence is very beneficial to the community. Almost the entire West Kalimantan area of 14,753,000 hectares is covered by forests, except for rivers, farms, and settlements (Sudrajat, 2016). Ketapang regency is the largest area of West Kalimantan whose forest ,based on Central Bureau of Statistics (BPS) record in 2017 ranged around 3,027,315.00 hectares, but by 2015 the forest area was 3,019,581.60 hectares. Those are for only customary forests. For more, indigenous forest is regulated by institutions and governed by law by considering the usefulness of indigenous peoples and their environment. Traditional forest in Ketapang is usually owned by the Dayak community.

The Dayaks are indigenous people who live in most of Ketapang. Farming is their main livelihood. The reduced forest area at a present led them to adapt and experience a shift in life orientation. According Dharmawan (2007) changes in livelihood strategies follow the social and ecological changes. Ketapang people at this time also begin to adopt a new farming system. Their behavior in utilizing natural resources in the form of forest is inseparable from the sociocultural system they have. The socio-cultural system that the community possesses is related to their knowledge of natural resources owned, understood, and implemented (Mubyarto et al., 1991).

Forest fires in Ketapang Regency, especially in indigenous forest, are caused by many factors, including the clearing of forests and oil palm plantations. The wisdom about clearing land in an environmentally friendly manner has been left behind, people no longer pay attention to customary law so that the forest becomes damaged and trigger forest fires and floods. Fires occur in the dry season. The fires barren forests into the fields of weeds. The friction of weeds and peatlands triggers a forest fire. The destruction of forests due to forest fires causes the absorption of soil to water decreases and triggers flooding in the rainy season. The following are the disaster data due to forest destruction that occurred in Ketapang Regency.

One of efforts to conserve customary forests from damage done by communities is by revitalizing oral traditions. Public education on the need to conserve forests is an integral part of the effort to overcome the destruction of customary forests. Therefore, this study aimed to explore the values contained in the oral tradition and develop the potential of oral tradition in the development of customary forest. conservation efforts in Ketapang District. This research is in line with Oikawa (2014) which finds the concept 
of community based disaster education and Disaster Risk Reduction by involving the people in the scrutiny by Chen (2006), Zhang (2013), and Lou (2013). Research conducted in Ketapang is more to disaster risk reduction which is caused by forest destruction with oral tradition approach.

Table 1. The Disjaster Data in Ketapang Regency

\begin{tabular}{|c|c|c|c|}
\hline No & Sub-district & $\begin{array}{l}\text { Forest } \\
\text { fires }\end{array}$ & Flood \\
\hline 1 & Kendawangan & 3 locations & $\begin{array}{l}3 \\
\text { locations }\end{array}$ \\
\hline 2 & $\begin{array}{l}\text { Matan Hilir } \\
\text { Utara }\end{array}$ & 2 locations & - \\
\hline 3 & $\begin{array}{l}\text { Matan Hilir } \\
\text { Selatan }\end{array}$ & 4 locations & $\begin{array}{l}2 \\
\text { locations }\end{array}$ \\
\hline 4 & Benua kayong & 1 location & - \\
\hline 5 & Marau & 1 location & $\begin{array}{l}6 \\
\text { locations }\end{array}$ \\
\hline 6 & Nanga Tayap & 2 locations & $\begin{array}{l}9 \\
\text { locations }\end{array}$ \\
\hline 7 & Delta Pawan & 1 location & $\begin{array}{l}4 \\
\text { locations }\end{array}$ \\
\hline 8 & Sui laur & - & $\begin{array}{l}12 \\
\text { locations }\end{array}$ \\
\hline 9 & Hulu sungai & - & $\begin{array}{l}11 \\
\text { locations }\end{array}$ \\
\hline 10 & Tumpang Titi & - & $\begin{array}{l}9 \\
\text { locations }\end{array}$ \\
\hline 11 & Sandai & - & $\begin{array}{l}8 \\
\text { locations }\end{array}$ \\
\hline 12 & $\begin{array}{l}\text { Jelai Hulu } \\
\text { total } \\
\text { disasters }\end{array}$ & $\begin{array}{l}14 \\
\text { locations }\end{array}$ & $\begin{array}{l}5 \\
\text { locations } \\
\mathbf{5 9} \\
\text { locations }\end{array}$ \\
\hline
\end{tabular}

Source: Focused Group Discussion with Dayak Communities

\section{Methods}

This study was conducted in Ketapang, West Kalimantan. The method used was qualitative. The sources of data were informants, places and events, and documents. The informant were the Dayak community in Ketapang, while the investigated event was the life of the Dayak community. To strengthen the data, the researchers studied any documents that exist in the Institute of Dayakologi. Meanwhile, the data collection techniques used were direct observation techniques, deep interviews, and document studies. The sampling technique used was purposive sampling. The collected data were validated by using triangulation, and data analysis techniques using interactive analysis.

\section{Results and Discussion}

The destruction of customary forests in Ketapang District was caused by several factors, including central government policy on forest governance and human error in managing forests. The Government passed Forestry Law No.5 / 1967 and Government Regulation No.21 / 1967 on legal basis in allowing concession of forest concession for 20-25 years, log cutting and forest industry (plywood) (Hidayat, 2011). The impact was 75 companies holding HPH concessions with a total permit area reaching $46.60 \%$ of the total area of West Kalimantan Province (Alqadrie, 1994). Forest clearing to meet the needs of life such as settlements, plantations and agricultural areas often abandoned the local wisdom developed in the community. This led to forest destruction and reduced forest area which required them to adapt and shift the orientation of life. According Dharmawan (2007) changes in livelihood strategies follow the social and ecological changes. Ketapang people at this time also began to adopt a new farming system,. Their behavior in utilizing natural resources in the form of forest is inseparable from the sociocultural system they have. The socio-cultural system that the community possesses is related to their knowledge of natural resources owned, understood, and implemented (Mubyarto et al., 1991).

Indigenous forest fires occur because people do not obey to the principles of natural resource management. Indigenous peoples, especially Dayak Jalai have a natural resource management system that combines aspects of independence, sustainability, integrative benefit. These three aspects are the life principles of Dayak Jalai indigenous people, which are reflected in the 7 principles of customary forest management. The 7 principles of customary forest management include; 1) continuity, 2) togetherness, 3) natural, 4) Spirituality, 5) Process, 6) Subsistence, and 7) Customary law (Bamba, 2010).

Forest fires by logging companies are not environmentally friendly. This is against Dayak indigenous people. Forest clearance by companies owning Forest Management Rights (HPH) was done by burning forests to make operational costs of forest clearing cheap. On the other hand, forest clearing for the fields by Dayak indigenous peoples is usually done by using traditional insights. Before burning the forest they make fire springs along 2-3 meters so 
that fire does not spread to the forest. The spirit of protecting the forests by Dayak because they see nature as not an asset or other properties like a shared house (Bamba, 1996).

The Movement of indigenous people in Ketapang District of West Kalimantan in safeguarding the forests is part of the social movement. As a social movement, the conscious movement of the environment is a collective effort to create a more just environmental order (Situmorang, 2013). Boomgaard's study shows that although the forest conservation movement has begun during the colonial period, but until the end of Dutch rule the movement was still elitist and limited to its supporters (Nawiyanto, 2012). Environmental movement that occurred in the Ketapang community was a voluntary movement because it triggered the destruction of forests that became the source of life both economic, social, cultural and religious. The following are examples of a social movement conducted by indigenous peoples in Ketapang in preventing forest destruction;

Table 2. Social movement conducted by indigenous people in Ketapang

\begin{tabular}{|c|c|c|c|c|c|}
\hline No & Perpetrators & Violation & Scene & Time & $\begin{array}{l}\text { Movement of } \\
\text { Indigenous Peoples }\end{array}$ \\
\hline 1 & $\begin{array}{l}\text { PT Kayong } \\
\text { Argo Lestari }\end{array}$ & $\begin{array}{l}\text { Pollution of } \\
\text { the Manjau } \\
\text { river }\end{array}$ & $\begin{array}{l}\text { Village } \\
\text { laman } \\
\text { Satong } \\
\text { Subdistrict } \\
\text { Matan Hilir } \\
\text { Utara }\end{array}$ & April 2011 & $\begin{array}{l}\text { The } 10 \text { real estate fine } \\
\text { means } 40 \text { crocks or } 40 \\
\text { dishes }\end{array}$ \\
\hline 2 & $\begin{array}{l}\text { PT Gala } \\
\text { Primajaya, } \\
\text { contractor from } \\
\text { PT Bangun } \\
\text { Nusantara } \\
\text { Mandiri }\end{array}$ & $\begin{array}{l}\text { evictions of } \\
\text { cultivation } \\
\text { areas, rubber } \\
\text { gardens, fruit } \\
\text { orchards and } \\
\text { graves. }\end{array}$ & $\begin{array}{l}\text { Silat Hulu } \\
\text { upstream, } \\
\text { village } \\
\text { Batansari, } \\
\text { Marau } \\
\text { Subdistrict. }\end{array}$ & $\begin{array}{l}\text { September } \\
29,2009\end{array}$ & $\begin{array}{l}\text { Foreclosure of } 2 \text { units of } \\
\text { bulldozers and one unit } \\
\text { of durolit as evidence to } \\
\text { be discussed in } \\
\text { customary law } \\
\text { deliberations }\end{array}$ \\
\hline 3 & $\begin{array}{l}\text { PT Sandhika } \\
\text { Nata Palma dan } \\
\text { PT Budidaya } \\
\text { Argo lestari. }\end{array}$ & $\begin{array}{l}\text { destroying } \\
\text { forests and } \\
\text { displacing } \\
\text { community } \\
\text { cemeteries }\end{array}$ & $\begin{array}{l}\text { Subdistrict } \\
\text { Kenda } \\
\text { wangan }\end{array}$ & July 1997 & $\begin{array}{l}\text { punishing Customary } \\
\text { for land violation colap } \\
\text { Taruth pusaka Bukit }\end{array}$ \\
\hline
\end{tabular}

Source: Focused Group Discussion with Dayak Communities

Social movement conducted by Dayak community was done by custom approach through law enforcement custom. Customary law is an unwritten law so that any attempts to convert a customary law into writing is a form of harassing the purity and privilege of customary law as a guide and moral foundation of Dayak indigenous peoples (Bamba, 2010). The punishment for the forest destroyer depends on the losses incurred, for example the flameaffected plant only withered its fine is 1 bowl of rice and nails, but if the plant dies then add 4 bowls of rice and a machete / knife, the dead plant must remain in the dressing (Kihi, 2010).

\section{Educational Values of Oral Tradition of Dayak Communities}

Religious values have always been central to every oral tradition that flourished in the
Ketapang community. For the Dayak people religious values are always inherent in everyday life, every activity begins with a ritual to the creator. The belief in the creator teaches the people to keep the forest from damage, because if the forest is damaged then they cannot do ritual and cope.

The Value of Care for the Universe / Environment Dayak community in Ketapang can be seen from their efforts in protecting and preserving the forest. The ancestors of the Dayak community in Ketapang have seen that one day there will be a natural disaster, therefore they have advised the advice on the importance of maintaining the natural surroundings either through fairy tales or customary law. Here are some examples of customary laws that serve to conserve forests in Dayak communities in Ketapang District 
Tabel 3. Customary laws that serve to conserve forests in Dayak communities

\begin{tabular}{|c|c|c|}
\hline No & $\begin{array}{l}\text { Forms of } \\
\text { Violation }\end{array}$ & Customary Sanctions \\
\hline 1 & $\begin{array}{l}\text { Damaging fruit } \\
\text { trees }\end{array}$ & $\begin{array}{l}16 \text { traditional bowls, } 2 \\
\text { bottles of palm wine }\end{array}$ \\
\hline 2 & $\begin{array}{l}\text { Cut down a } \\
\text { sacred tree }\end{array}$ & $\begin{array}{l}2 \text { chickens, } 2 \text { dozen tuak, } \\
10 \text { regular rice kulak, } 5 \\
\text { kulak rice pulut, } 15 \mathrm{~kg} \\
\text { pig, }\end{array}$ \\
\hline 3 & $\begin{array}{l}\text { Burn the forest } \\
\text { and spread to the } \\
\text { shrine }\end{array}$ & $\begin{array}{l}2 \text { chickens, } 2 \text { dozen tuak, } \\
10 \text { regular rice kulak, } \\
\text { kulak rice pulut, } 15 \mathrm{~kg} \text { pig }\end{array}$ \\
\hline 4 & $\begin{array}{l}\text { Fishing in the } \\
\text { forbidden place }\end{array}$ & $\begin{array}{l}1 \text { chicken and } 4 \text { bottles of } \\
\text { palm wine }\end{array}$ \\
\hline 5 & $\begin{array}{ll}\text { Merusak } & \text { pohon } \\
\text { yang } & \text { sudah } \\
\text { produktif } & \end{array}$ & Crock or 2 antique dishes \\
\hline
\end{tabular}

Source: Focused Group Discussion with Dayak Communities

Through Dayak, customary law was taught how to keep the forest from damage. The community was taught how to preserve nature through severe punishment and social sanction if they violate customs related to customary forest.

The value of togetherness and mutual cooperation is a noble value that inherited from generation to generation. Teamwork activities are done when preparing traditional ceremonies, clearing land and maintaining public facilities. The teamwork activities will shape the character of the community that has a high social awareness and environmental awareness so that it can reduce the risk of forest damage caused by fire.

\section{Oral Tradition in Customary Forest Conservation Efforts in Ketapang District.}

The educational values that exist in the oral tradition will lead people to do good. One of them is keeping the forest from damage. The religious value that exists in the oral tradition of Dayak indigenous peoples is an attitude and behavior that adheres to the religious teachings it embraces, including how to preserve the forest. For forest, Dayak people considere it not only as a place to find the source of life, but the place to achieve religious value. All the needs for worshiping the Dayak community, especially customary rituals can be found in the forest. The value of social care is part of a shared solidarity in disaster mitigation efforts such as forest destruction. The environmental value that exists in Dayak's oral traditions are attitudes and actions that always seek to prevent forest destruction, such as protecting rivers, springs, and trees from destruction through the myths of developing myths. Fairy tales can be made as environmental learning, as does Freund's research (2015) which examines the benefits of fairy tales and oral history in the American public.

Oral tradition of the Dayak community in Ketapang can be used as a source of learning and learning media in an effort to preserve indigenous forest. As a source of learning, the values contained in the oral tradition are full of educational elements that can be developed as a means of enforcement, mobilization and socialization of the importance of environmental awareness as a preventive form of forest sustainability. The essence of the educative values in the oral tradition of the Dayak community is the embodiment of values education, namely the noble values education that is sourced from the culture of the Indonesian nation itself, in order to foster the personality of the young generation (Mulyana, 2004).

The values of social care and environmental concerns that exist in the oral tradition are sources of learning for the community in an effort to reduce forest destruction. Dayak oral traditions of the Dayak community in Ketapang can be made a source of learning through the cultural community. Research conducted by Chen (2006) explains the efficiency of disaster risk reduction through community-based disaster management program with community involvement can be applied in Ketapang community which has community, especially indigenous community. This is in accordance with the theory of Illich ivan disaster education. Disaster education theory developed by Illich (1994) is to train and educate the community to get preparedness by utilizing the wisdom of society, because the people have the wisdom to respond to the environment, meaning the more people are able to take advantage of local wisdom then by itself people will be more alert to disaster. Training communities to care for the preservation of customary forests is a part of the response to forest destruction through interaction with the environment. Vygotsky argues that interaction of one's interaction with the environment can aid learning (Schunk, 2012). Ketapang community interact with the environment and use it for learning inherited from generation to generation through indigenous communities. 
The concept of Zone of Proximal development (ZPD) Vygotsky in the development and learning of children's actions is still influenced or assisted by others. The act of preserving the forest can be exemplified to children and youth through the performing arts of oral tradition. Fernandez (2013) states that disaster risk reduction by involving youth is effective because youth have high morale. Youth as a creative generation is expected to revitalize the oral tradition in accordance with the times. Revitalization of oral tradition is part of cultural conservation.

Oral tradition as a medium for learning of indigenous peoples should be deconstructed. Decorating oral traditions by way of a mythical and mythical story is one way to be easy to understand. Vygotsky's scaffolding concept can be applied by oral tradition deconstruction approach to build public awareness about forest destruction. As a result the community will be aware of its responsibilities because since the beginning has been educated to guide other people who have not understood the impact of forest destruction by way of continuous mentoring.

\section{Conclusion}

Values of oral tradition in the Dayak community can be made as a source of learning and learning media for the community. Religious values, togetherness, mutual assistance, social care, and caring are the values that can educate the Dayak people in maintaining the forest from damage. As a source of learning, the values contained in the oral tradition are full of educational elements that can be developed as a means of enforcement, mobilization and socialization of the importance of environmental awareness as a preventive form of forest sustainability. Through learning by utilizing the value of oral traditions, it will form the character of the community that has a social awareness and high environmental awareness that can reduce the risk of forest fires. Oral tradition can also be used as a medium of community learning, for example as an educational performing arts. Oral tradition as performing arts is also part of cultural conservation.

\section{References}

Alqadrie S.I. (1994). Dampak Perusahaan Pemegang HPH dan Perkebunan terhadap Kehidupan Sosial Ekonomi dan Budaya Penduduk Setempat di Daerah Pedalaman Kalimantan Barat.. Jakarta: PT Grasindo.

Bamba, J. (1996). Pengelolaan Sumber Daya Alam: Menurut Budaya Dayak dan Tantangan yang di Hadapi. Kalimantan Review, No. 15 Year V, March-April 1996, Pontianak.

Bamba, J. (2010). Dayak Jalai Di Persimpangan Jalan. Pontianak: Institut Dayakologi.

Chen, Liang-Chun. Yi-Chung Liu, Kuei-Chi Chan. (2006). Integrated CommunityBased Disaster Management Program in Taiwan: A Case Study of Shang-An Village. Natural Hazards. 37(2006), 209-223.

Dharmawan A.H. (2007). Sistem Penghidupan dan Nafkah Pedesaan: Pandangan Sosiologi Nafkah (Livelihood Sociology) Mazhab Barat dan Mazhab Bogor. Jurnal Transdisiplin Sosiologi, Komunikasi, dan Ekologi Manusia. 1(2), 169-192.

Fernandez, Glenn and Rajib Shaw. (2013).Youth Council Participation in Disaster Risk Reduction in Infanta and Makati, Philippines: A Policy Review. Int. J. Disaster Risk. 4 (3), 126-136.

Freund, Alexander.(2015). Under Storytelling's Spell? Oral History in a Neoliberal Age. The Oral History Review, 96132.

Hidayat, Herman. (2011). Politik Lingkungan: Pengelolaan Hutan Masa Orde baru dan Reformasi. Jakarta: Yayasan Obor.

Illich, Ivan. (1994). "Deschooling Society". London: Caldar \& Boyars Ltd.

Kihi, Stephanus.(2010). Adat Istiadat, Hukum Adat, \& Kesepakatan Adat Desa Cenayan. Pontianak: PPSDAK Pancur Kasih.

Lou, Xiaofeng and Annette E. Levi. (2013). Factors influencing willingness to participate in disaster reduction. Nat Hazards . 66(2013), 1243-1255.

Mubyarto, et. al. (1991). Kajian Sosial Ekonomi Desa-Desa Perbatasan di Kalimantan Timur. Yogyakarta: Aditya Media.

Mulyana, Rohmat. (2004). Mengartikulasikan Pendidikan Nilai. Bandung: Alfabeta.

Nawiyanto. (2012). Bencana dan Pelestarian Lingkungan: Pandangan Etnik Jawa 
dan Madura Di Wilayah Ujung Timur Jawa. Paramita. 22 (1), 41-55.

Oikawa,Y.and S.Rajib.(2014). Education for Sustainable Development and Disaster Risk Reduction. Retrieved from https://www.springer.com/gp/book/97 84431550891

Situmorang, Abdul Wahib. (2013). Dinamika Protes Kolektif Lingkungan Hidup di Indonesia, 1968-2011. Yogyakarta: Pustaka Pelajar.
Sudrajat, Jajat.(2016). .Sejarah Pemanfaatan Sumber Daya Hutan Dan Pergeseran Nafkah Suku Dayak Di Kalimantan Barat. Paramita. 26 (2), 230-243.

Zhang, Xi . Lixin Yi, Dong Zhao. (2013). Community-based disaster management: a review of progress in China. Nat Hazards. 65 (2013), 22152239. 